\title{
BEHAVIOR OF BREAST SELF EXAMINATION (BBS) ON FEMALE STUDENTS IN SMA NEGERI 6 PEKANBARU YEARS 2016
}

\author{
Riri Maharani, Lisa Fransisca \\ Program Studi Ilmu Kesehatan Mayarakat STIKes Hang Tuah Pekanbaru \\ Email: riri_maharani@yahoo.co.id
}

\begin{abstract}
Breast Self Examination (BSE) is an examination technique where one woman check her own breasts with a look and feel with a finger to detect whether or not there is a lump in her breast (Djawarut, 2014). BSE is one way to detect breast cancer early. According Sutjipto, at this time have been found with breast cancer at a young age. This study aims to determine the behavior of adolescent girls in SMA 6 Pekanbaru 2016.

This type of research is a quantitative analytical research. With design cross- sectional. The sample was SMA Negeri 6 Pekanbaru class X and XI which totaled 129 with a population of 371 people. The sampling technique used is stratified random sampling. The analysis used were univariate and bivariate with Chi Square test.

Based on the results of the study showed most respondents did conduct BSE in 2 (1.6\%), respondents with low knowledge, 104 (100\%), respondents with negative attitudes were 107 (100\%), respondents were not doing as much as 110 (100\%), respondents who never get as much information as much as 105 (100\%), and respondents who have no family support as many as 106 (100\%), Based on the statistical test $P$ value obtained from five variables $<\alpha$ (0.05), there is a significant relationship between knowledge, attitudes, actions, mass media and family support to conduct breast self-examination. Advice can be given is the school invited health authorities to work together to educate the student through counseling in an effort to improve reproductive health so that students know the importance of early behavioral measures BSE.
\end{abstract}

Keywords: $\quad$ Behavior BSE, Knowledge, Attitude, Action, Mass Media and Support family

\section{PENDAHULUAN}

Pemeriksaan Payudara Sendiri (SADARI) adalah suatu teknik pemeriksaan dimana seseorang wanita memeriksa payudaranya sendiri dengan melihat dan merasakan dengan jari untuk mendeteksi apakah ada benjolan atau tidak pada payudaranya (Djawarut, 2014). Pemeriksaan payudara sendiri (SADARI) sangat mudah untuk dilakukan akan tetapi pada kenyataannya tidak sedikit wanita yang bersikap acuh tak acuh dengan kondisi kesehatan organ reproduksinya (Mardiana, 2007). Pemeriksaan payudara sendiri (SADARI) merupakan salah satu cara mendeteksi dini kanker payudara.

Di Indonesia, berdasarkan data Sistem Informasi Rumah Sakit (SIRS), jumlah pasien rawat jalan maupun rawat inap pada kanker payudara terbanyak yaitu 12.014 orang $(28,7 \%)$, (Kemenkes RI, 2014).

Di Provinsi Riau tahun 2013 angka kejadian kanker payudara sebesar 0,3\% (Kemenkes,2015).
Berdasarkan data RSUD Arifin Achmad Pekanbaru, kanker payudara menempati urutan pertama penyakit terbanyak pada bedah umum dengan jumlah kasus 186 ditahun 2013 dan meningkat menjadi 294 pada tahun 2014. Kanker payudara umumnya menyerang wanita yang telah berumur lebih dari 40 tahun. Namun demikian, wanita muda pun bisa terserang kanker ini (Mardiana, 2007). Berdasarkan data pada tahun 2012 di Rumah Sakit Petala Bumi ada sebanyak 58 kasus yang terkena Neoplasma ganas payudara diantaranya yang berumur 15-24 tahun sebanyak 3 orang, pada usia 25-44 tahun sebanyak 27 orang, umur 45-64 tahun sebanyak 26 orang dan $>65$ tahun sebanyak 2 orang dan mengalami peningkatan pada tahun 2013 menjadi 68 kasus diantaranya yang berumur 15-24 tahun sebanyak 7 orang, pada usia 25-44 tahun sebanyak 33 orang, dan umur 45-64 tahun sebanyak 23 orang. 
Menurut Sutjipto, saat ini telah banyak ditemukan penderita kanker payudara pada usia muda, bahkan tidak sedikit remaja putri usia empat belas tahun menderita tumor di payudaranya. Dimana tumor yang terjadi bisa menjadi kanker, bila tidak terdeteksi lebih awal. Meskipun tidak semuanya ganas, tetapi ini menunjukkan bahwa saat ini sudah ada tren gejala kanker payudara yang semakin tinggi di usia remaja (Siahaan, 2008).

Menurut Wibisono, ada beberapa faktor risiko yang dapat menyebabkan seseorang terkena kanker payudara. Faktor risiko ini dapat berasal dari dalam maupun dari luar. Faktor dari dalam adalah adanya riwayat keluarga yang menderita kanker payudara, maka risiko terkena kanker payudara akan meningkat, sedangkan faktor dari luar diantaranya pola diet yang tidak baik dan seimbang, perilaku dan pola gaya hidup (life style) yang tidak sehat seperti merokok, minum alcohol dan jarang berolahraga (Siregar, 2010). Selain itu kurangnya kesadaran wanita untuk mendeteksi dini adanya kanker payudara juga merupakan penyebab tingginya kasus kanker payudara.

Tujuan Penelitian ini adalah untuk mengetahui perilaku pemeriksaan payudara sendiri (SADARI) dalam upaya deteksi dini kanker payudara pada siswi remaja di SMAN 6 pekanbaru tahun 2016.

\section{METODOLOGI PENELITIAN}

Jenis penelitian ini merupakan penelitian Analitik Kuantitatif dengan desain penelitian yang digunakan adalah cross sectional (potong lintang), yang dilaksanakan pada 21 April 2016 di SMAN 6 Pekanbaru. Jumlah sampel dalam penelitian ini sebanyak 129 responden yang terdiri dari kelas X sebanyak 67 responden dan kelas XI sebanyak 62 responden. Jenis data yang dikumpulkan adalah data sekunder, seperti jumlah keseluruhan siswa/i tahun ajaran 2015 dan jumlah kelas keseluruhan, data jumlah penderita kanker payudara di Rumah Sakit Arifin Achmad Pekanbaru tahun 2013-2014 dan Rumah Sakit Petala Bumi tahun 2012-2013. Selain data sekunder, data primer dilakukan dengan cara membagikan kuesioner yang memuat pertanyaan untuk menggali informasi tentang variabel dependen dan variabel indepen. Analisis bivariat dilakukan dengan uji Chi-Square.

\section{HASIL DAN PEMBAHASAN Hasil}

Analisis bivariat bertujuan untuk mengetahui hubungan antara variabel bebas dengan variabel terikat yang merupakan tujuan pada penelitian, dengan melakukan analisis bivariat ini maka akan didapati seberapa besar hubungan pengetahuan, sikap, tindakan, media massa, dan dukungan keluarga terhadap perilaku pemeriksaan payudara sendiri (SADARI) dalam upaya deteksi dini kanker payudara pada siswi remaja di SMAN 6 Pekanbaru.

Hubungan antara pengetahuan dengan perilaku pemeriksaan payudara sendiri dalam upaya deteksi dini kanker payudara pada siswi remaja di SMAN 6 Pekanbaru didapati hasil uji Chi-Square menunjukan $\mathrm{P}$ value $=0,036$ ( $\mathrm{P}$ value $<0,05)$ yang berarti ada hubungan yang signifikan antara pengetahuan responden dengan perilaku SADARI.

Hubungan antara sikap dengan perilaku pemeriksaan payudara sendiri dalam upaya deteksi dini kanker payudara pada siswi remaja di SMAN 6 Pekanbaru didapati hasil uji Chi-Square menunjukan $\mathrm{P}$ value $=0,028(\mathrm{P}$ valeu $<0,05)$ yang berarti ada hubungan yang signifikan antara sikap responden dengan perilaku SADARI.

Hubungan antara tindakan dengan perilaku pemeriksaan payudara sendiri dalam upaya deteksi dini kanker payudara pada siswi remaja di SMAN 6 Pekanbaru didapati hasil uji Chi-Square menunjukan $\mathrm{P}$ value $=0,021(\mathrm{P}$ value $<0,05)$ yang berarti ada hubungan yang signifikan antara tindakan responden dengan perilaku SADARI.

Hubungan antara media massa dengan perilaku pemeriksaan payudara sendiri dalam upaya deteksi dini kanker payudara pada siswi remaja di SMAN 6 Pekanbaru didapati hasil uji Chi-Square menunjukan $\mathrm{P}$ value $=0,033$ ( $\mathrm{P}$ value $<0,05)$ yang berarti ada hubungan yang signifikan antara informasi (media massa) dengan perilaku SADARI.

Hubungan antara dukungan keluarga dengan perilaku pemeriksaan payudara sendiri dalam 
upaya deteksi dini kanker payudara pada siswi remaja di SMAN 6 Pekanbaru didapati Hasil uji Chi-Square menunjukan P value $=0,015$ ( $\mathrm{P}$ value $<0,05)$ yang berarti ada hubungan yang signifikan antara dukungan keluarga dengan perilaku SADARI.

Tabel 1

Resume Variabel Analisis Bivariat

\begin{tabular}{|c|c|c|c|c|c|c|c|c|}
\hline \multirow{3}{*}{ Pengetahuan } & \multicolumn{4}{|c|}{ SADARI } & \multirow{2}{*}{\multicolumn{2}{|c|}{ Total }} & \multirow{3}{*}{$\begin{array}{c}\text { P- } \\
\text { Value }\end{array}$} & \multirow{3}{*}{$\begin{array}{c}\text { POR (CI) } \\
95 \%\end{array}$} \\
\hline & \multicolumn{2}{|c|}{ Tidak Melakukan } & \multicolumn{2}{|c|}{ Melakukan } & & & & \\
\hline & $\mathbf{n}$ & $\%$ & $\mathbf{n}$ & $\%$ & $\mathbf{N}$ & $\%$ & & \\
\hline Rendah & 104 & 100 & $\mathbf{0}$ & $\mathbf{0}$ & 104 & 100 & 0,036 & 1.087 \\
\hline Tinggi & 23 & 92 & 2 & 8,0 & 25 & 100 & & \\
\hline Total & 127 & 98,4 & 2 & 1,6 & 129 & 100 & & $\begin{array}{l}(0.968- \\
1.220)\end{array}$ \\
\hline Sikap & & 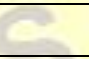 & 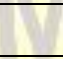 & 1 & +7 & & & \\
\hline Negatif & 107 & 100 & $\mathbf{0}$ & $\mathbf{0}$ & 107 & 100 & 0,028 & 1.100 \\
\hline Positif & 20 & 90,9 & 2 & 9.1 & 22 & 100 & & \\
\hline Total & 127 & 98.4 & 2 & 1.6 & 129 & 100 & & $(0.964-$ \\
\hline Tindakan & & & & & & & & 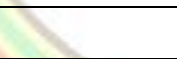 \\
\hline Tidak & 110 & 100 & $\mathbf{0}$ & $\mathbf{0}$ & 110 & 100 & 0,021 & 1.118 \\
\hline Melakukan & & & & & & & & \\
\hline Melakukan & 17 & 89,5 & 2 & 10,5 & 19 & 100 & & \\
\hline Total & 127 & 98.4 & 2 & 1.6 & 129 & 100 & & $\begin{array}{l}(0.958- \\
1.304)\end{array}$ \\
\hline F & Med & & & & 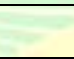 & & & 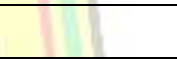 \\
\hline Tidak & 105 & 100 & $\mathbf{0}$ & $\mathbf{0}$ & 105 & 100 & $\mathbf{0 , 0 3 3}$ & 1.111 \\
\hline Pernah & 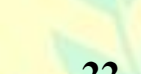 & & & & & & & \\
\hline Pernah & 22 & 91,7 & 2 & 8,3 & 24 & 100 & & $\begin{array}{l}(0.960- \\
1.286)\end{array}$ \\
\hline Total & 127 & 98.4 & 2 & 1.6 & 129 & 100 & & \\
\hline Dukunga & Keluarga & & & & & & 4 & \\
\hline $\begin{array}{c}\text { Tidak } \\
\text { mendukung }\end{array}$ & & 100 & $\mathbf{0}$ & $\mathbf{0}$ & 106 & 100 & $\mathbf{0}$ & 1.095 \\
\hline Mendukung & 21 & $\mathbf{9 1 , 3}$ & 2 & 8,7 & 23 & 100 & & $\begin{array}{l}(0.965- \\
1.242)\end{array}$ \\
\hline Total & 127 & 98.4 & 2 & 1.6 & 129 & 100 & & \\
\hline
\end{tabular}

Pembahasan

Hubungan Pengetahuan terhadap

Perilaku Pemeriksaan Payudara Sendiri (SADARI) pada Siswi Remaja SMA Negeri 6 Pekanbaru Tahun 2016

Berdasarkan hasil penelitian dilapangan ditemukan bahwa ada hubungan yang bermakna antara pengetahuan dengan perilaku pemeriksaan payudara sendiri pada siswi remaja di SMA Negeri 6 Pekanbaru, dapat dilihat dari hasil uji statistik Chi-Square dimana $\mathrm{P}$ value $=0,036(\mathrm{P}$ value <0,05).

Hasil penelitian ini didukung oleh teori yang dikemukakan oleh Notoatmodjo (2010), sebelum seseorang mengadopsi perilaku, ia harus tahu terlebih dahulu apa arti atau manfaat perilaku tersebut bagi dirinya. Berdasarkan pertanyaan tersebut dapat disimpulkan bahwa seseorang akan melakukan pemeriksaan payudara sendiri (SADARI) apabila ia tahu cara dan manfaat bagi 
dirinya. Pengetahuan menjadi faktor yang penting untuk menentukan perilaku SADARI seseorang, jika seseorang memiliki pengetahuan yang tinggi tentang SADARI maka tindakan untuk melakukan SADARI secara rutin berjalan dengan baik dan sebaliknya jika seseorang memiliki pengetahuan yang rendah tentang SADARI maka tindakan untuk melakukan SADARI secara rutin tidak akan berjalan dengan baik.

Hasil penelitian ini sejalan dengan penelitian yang dilakukan Handayani (2008), menyatakan bahwa terdapat hubungan yang signifikan antara tingkat pengetahuan dengan perilaku dalam melakukan pemeriksaan payudara sendiri dimana diperoleh $(p$ value $=0,015)$, dan sejalan dengan penelitian Djawarut (2014), menyatakan bahwa ada hubungan yang bermakna antara pengetahuan dengan pemeriksaan payudara sendiri (SADARI), dengan hasil analisis diperoleh nilai $p=0,021<\alpha=(0,05)$.

Menurut asumsi peneliti, dari hasil penelitian mayoritas siswi berpengetahuan rendah. Hal ini dikarenakan kurangnya informasi tentang cara mendeteksi dini kanker payudara menggunakan metode SADARI, sehingga mereka cenderung tidak memiliki pengetahuan yang baik mengenai SADARI dalam upaya deteksi dini kanker payudara, dapat dilihat masih banyaknya responden yang tidak melakukan SADARI dikarenakan mereka tidak memahami tujuan dan manfaat dilakukannya SADARI, hal ini terlihat dari jawaban responden pada pertanyaan tujuan dan manfaat SADARI mayoritas responden menjawab salah.

Hubungan Sikap terhadap Perilaku Pemeriksaan Payudara Sendiri (SADARI) pada Siswi Remaja SMA Negeri 6 Pekanbaru Tahun 2016

Berdasarkan hasil penelitian dilapangan tentang hubungan antara Sikap dengan perilaku SADARI pada siswi remaja di SMA Negeri 6 Pekanbaru didapati uji statistik Chi-Square dimana $\mathrm{P}$ value $=0,028$ ( $\mathrm{P}$ value $<0,05)$.

Menurut Dinawati, sikap wanita untuk menyadari pentingnya pemeriksaan payudara sendiri untuk mencegah resiko kanker payudara dapat meningkatkan kesadaran para wanita khususnya remaja untuk memotivasi diri sendiri mempraktekan secara langsung pemeriksaan payudara sendiri sehingga mengetahui kondisi payudaranya (Merdekayanti, 2014). Begitu pula teori dalam Notoatmodjo bahwa sikap adalah respon individu yang masih bersifat tertutup terhadap suatu rangsangan dan sikap tidak bisa diamati secara langsung oleh individu lain. Sikap merupakan suatu produk dari proses sosialisasi dimana seseorang beraksi sesuai dengan rangsangan yang diterimanya dan sikapnya belum tentu merupakan tindakan yang aktif, tetapi merupakan tindakan presdiposisi (pemungkin) dari tingkah laku.

Berdasarkan hasil penelitian Hanifah (2015) menunjukan bahwa ada hubungan antara sikap deteksi dini kanker payudara metode SADARI dengan perilaku SADARI wanita usia subur di Wilayah Kerja Puskesmas Nusukan Kota Surakarta dengan $p$-value $0,005<0,05$.

Berdasarkan hasil penelitian, Peneliti berasumsi bahwa melalui sikap dapat dilihat kecenderungan seseorang dalam bertindak, karena pada dasarnya sikap dapat sejalan dengan tindakan. Apabila sikap negatif terhadap SADARI maka cenderung untuk tidak melakukan SADARI dan sebaliknya apabila seseorang memiliki sikap positif terhadap suatu hal seperti menjaga kesehatan payudaranya, maka ia akan bertindak kearah yang lebih baik dengan melakukan SADARI.

\section{Hubungan Tindakan terhadap Perilaku SADARI}

Berdasarkan hasil penelitian dilapangan tentang hubungan antara tindakan melakukan pemeriksaan payudara sendiri dengan perilaku SADARI pada siswi remaja di SMA Negeri 6 Pekanbaru didapati uji statistik Chi-Square dimana $\mathrm{P}$ value $=0,021$ ( $\mathrm{P}$ value $<0,05)$.

Menurut Notoatmodjo (2012) untuk mewujudkan sikap menjadi suatu perbuatan yang nyata (praktik/tindakan) diperlukan faktor pendukung atau suatu kondisi yang memungkinkan, antara lain fasilitas.

Penelitian ini sejalan dengan yang dilakukan Sari (2015), menyatakan bahwa terdapat 
hubungan yang signifikan antara tindakan dengan SADARI sebagai deteksi dini kanker payudara $(\mathrm{p}=0,012)$.

Dari hasil penelitian diatas peneliti berasumsi bahwa tindakan erat kaitannya dengan perilaku seorang yang memiliki tindakan negatif cenderung tidak melakukan perilaku SADARI dikarenakan tidak mengetahui cara melakukannnya, berbeda dengan seorang yang memiliki tindakan positif dia akan rutin melakukan tindakan SADARI karena mngetahui cara dan manfaatnya bagi kesehatan.

\section{Hubungan Media Massa (Informasi) terhadap Perilaku SADARI}

Berdasarkan hasil penelitian dilapangan tentang hubungan antara Media Massa dengan perilaku SADARI pada siswi remaja di SMA Negeri 6 Pekanbaru didapati uji statistik ChiSquare dimana $\mathrm{P}$ value $=0,033(\mathrm{P}$ value $<0,05)$.

Menurut Notoatmodjo (2008) bahwa semakin banyak informasi dapat memengaruhi atau menambah pengetahuan seseorang dan dengan pengetahuan menimbulkan kesadaran yang akhirnya seseorang akan berperilaku sesuai dengan pengetahuan yang dimilikinya.

Hal ini sejalan dengan penelitian yang dilakukan oleh Kurnianingsih (2009) menunjukan bahwa media massa mempengaruhi tentang pencegahan penyakit terutama kanker payudara Tanjung (2012).

Berdasarkan penelitian diatas, peneliti berasumsi bahwa masih kurangnya informasi kesehatan terutama tentang deteksi dini kanker payudara menggunakan metode SADARI yang diberikan oleh tenaga kesehatan, sebagian dari mereka juga mengatakan bahwa pernah mendengar informasi tentang kanker payudara namun belum pernah mendapatkan informasi cara mendeteksi dini kanker payudara menggunakann metode SADARI. Dan juga kurangnya kesadaran siswi untuk mencari informasi kesehatan terutama informasi mengenai kesehatan payudara, seperti mencari tahu bagaimana cara mendeteksi dini kanker payudara, apa saja metode untuk mendeteksi kanker payudara. Kurangnya informasi kesehatan yang mereka dapat sangat berpengaruh terhadap tingkat pengetahuan dan juga tindakan mereka dalam beperilaku pemeriksaan payudara sendiri (SADARI).

\section{Hubungan Dukungan Keluarga terhadap Perilaku SADARI}

Berdasarkan hasil penelitian dilapangan tentang hubungan antara Dukungan Keluarga dengan perilaku SADARI pada siswi remaja di SMA Negeri 6 Pekanbaru didapati uji statistik Chi-Square dimana $\mathrm{P}$ value $=0,015$ (P value < $0,05)$.

Hal ini sejalan dengan hasil penelitian yang dilakukan Septiani (2013) terdapat hubungan yang signifikan antara dukungan orang tua/keluarga dengan perilaku SADARI pada siswa SMAN 62 Jakarta tahun 2012.

Menurut Friedman (2010), dukungan keluarga diartikan sebagai bantuan yang diberikan oleh anggota keluarga yang lain sehingga akan memberikan kenyamanan fisik dan psikologis. Keluarga merupakan orang terdekat dengan responden dalam hal berinteraksi dan mengambil keputusan terutama dalam hal menentukan kemana akan mencari pertolongan atau pengobatan.

Oleh karena itu peran keluarga merupakan pendukung untuk terjadinya perubahan perilaku kesehatan. Masih kurangnya informasi yang diberikan tentang SADARI dan banyaknya informasi yang salah akan mempersulit siswi dalam mendapatkan pengetahuan dan meningkatkan perilaku kesehatan. Sehingga dalam mendapatkan informasi yang benar siswi tidak hanya bergantung kepada informasi yang diberikan oleh keluarga, siswi juga harus mencari informasi melalui berbagai media massa seperti internet, TV, majalah dan mengikuti seminar kesehatan.

Hal ini disebabkan masih kurangnya peran dukungan keluarga dalam memberikan informasi tentang kanker payudara serta cara mendeteksi dininya menggunakan metode SADARI dan juga kurangnya peran keluarga dalam mengingatkan siswi untuk melakukan SADARI. Hal ini terlihat dari jawaban responden pada pertanyaan apakah keluarga selalu mengingatkan untuk melakukan SADARI? Mayoritas menjawab tidak pada 
pertanyaan tersebut. Dan menurut asumsi peneliti hal ini menjadi salah satu faktor siswi tidak melakukan SADARI karena tidak mendapat dukungan/dorongan keluarga untuk siswi melakukan SADARI sebagai upaya deteksi dini kanker payudara sekaligus upaya menjaga kesehatan reproduksi.

\section{KESIMPULAN DAN SARAN}

\section{Kesimpulan}

Berdasarkan hasil penelitian dapat disimpulkan bahwa ada hubungan antara pengetahuan, sikap, tindakan, media massa dan dukungan keluarga terhadap perilaku pemeriksaan payudara sendiri (SADARI).

\section{Saran}

Meningkatkan pengetahuan siswi dengan lebih meningkatkan upaya pencegahan dan promosi serta kerja sama dengan instansi kesehatan kegiatan seperti penyuluhan dapat berjalan dengan baik.

\section{UCAPAN TERIMAKASIH}

Ucapan terima kasih ditujukan kepada SMAN 6 Pekanbaru dan siswi kelas X dan XI.

\section{DAFTAR PUSTAKA}

Djawarut, Amier. (2014). Faktor-Faktor yang Berhubugan dengan Pemeriksan Payudara Sendiri (SADARI) pada Siswi SMK PGRI Kabupaten Pangkep, (Online), Vol.5,No.2, (http://library.stikesnh.ac.id/files/disk1/1 3/elibrary\%20stikes\%20nani\%20hasanu ddin--hildaamier-622-1-52141571-

1.pdf) Diakses 13 Januari 2016

Handayani, S. D. (2008). Hubungan Antara Tingkat Pengetahuan dan Sikap dengan Perilaku Para Wanita Dewasa Awal Dalam Melakukan Pemeriksaan Payudara Sendiri di Kelurahan Kalangan Kecamatan Pedan Klaten. (Online).(https://core.ac.uk/download/fil es/379/11715950.pdf) Diakses 12 Januari 2016

Hanifah, N. A. (2015). Faktor-Faktor yang Berhubungan dengan Perilaku Wanita
Usia Subur Dalam Melakukan Deteksi Dini Kanker Payudara Metode SADARI di Wilayah Kerja Puskesmas Nusukan Surakarta. Skripsi: Program Studi Kesehatan Masyarakat Fakultas Ilmu Kesehatan Universitas Muhammadiyah Surakarta

KemenKes RI. (2014). Hilangkan Mitos Tentang Kanker.

(Online). (http://www.depkes.go.id/article/view/2 01407070001/hilangkan-mitos-tentangkanker.html) Diakses 31 Desember 2015

KemenKes RI. (2015). Buletin Jendela Data dan Informasi Kesehatan Situasi Penyakit Kanker.

(https://www.scribd.com/doc/29130510 2/buletin-kanker) Diakses 31 Desember 2015

Mardiana, L. (2007). Kanker Pada Wanita, Pencegahan dan Pengobatan dengan Tanaman Obat. Jakarta: Penebar Swadaya

Merdekayanti, Dewi, Trisnadewi. (2014). Hubungan Tingkat Pengetahuan dan Sikap Remaja Putri Tentang Kanker Payudara dengan Perilaku Melakukann Pemeriksaan Payudara Sendiri. (Online).(http://stikeswiramedika.ac.id/ wp-content/uploads/2014/10.pdf)

Diakses 13 Januari 2016

Notoatmodjo. (2010). Promosi Kesehatan Teori dan Aplikasi. Jakarta: Rineka Cipta. (2012). Promosi Kesehatan dan Perilaku Kesehatan. Jakarta: Rineka Cipta

Sari, P. D. (2015). Hubungan Pengetahuan, Sikap dengan Tindakan Sadari Sebagai Deteksi Dini Kanker Payudara pada Mahasiswi di Fakultas Kesehatan Masyarakat Universitas Sumatera Utara. Skripsi: Fakultas Kesehatan Masyarakat Universitas Sumatera Utara

Septiani, S. (2012). Faktor-Faktor yang Berhubugan dengan Perilaku Pemeriksan Payudara Sendiri pada Siswa SMAN 62 Jakarta, (Online), Vol.5,No.1,

(http://lp3m.thamrin.ac.id/upload/artikel 
\%206.\%20vol\%205\%20no\%201_sari.p

df) Diakses 13 Januari 2016

Siahaan, M. (2008). Giliran Remaja yang Diincar Kanker Payudara. (Online). (https://gaya.tempo.co/read/news/2008/0 9/02/060133370/giliran-remaja-yangdiincar-kanker-payudara) Diakses 16 Januari 2016

Siregar, H. P. (2010). Analisis Perilaku Pencegahan Kanker Payudara pada
Remaja Putri di SMK Negeri 3 Pekanbaru. Skripsi: Program Studi Ilmu Kesehatan Masyarakat STIKes Hang Tuah Pekanbaru.

Tanjung, M. (2012). Gambaran Perilaku Siswi dalam Pemeriksaan Payudara Sendiri (SADARI) di SMA Plus Saffiatul Amaliyyah Medan, (Online), (http://repository.usu.ac.id/handle/12345 6789/34477) Diakses 12 Januari 2016

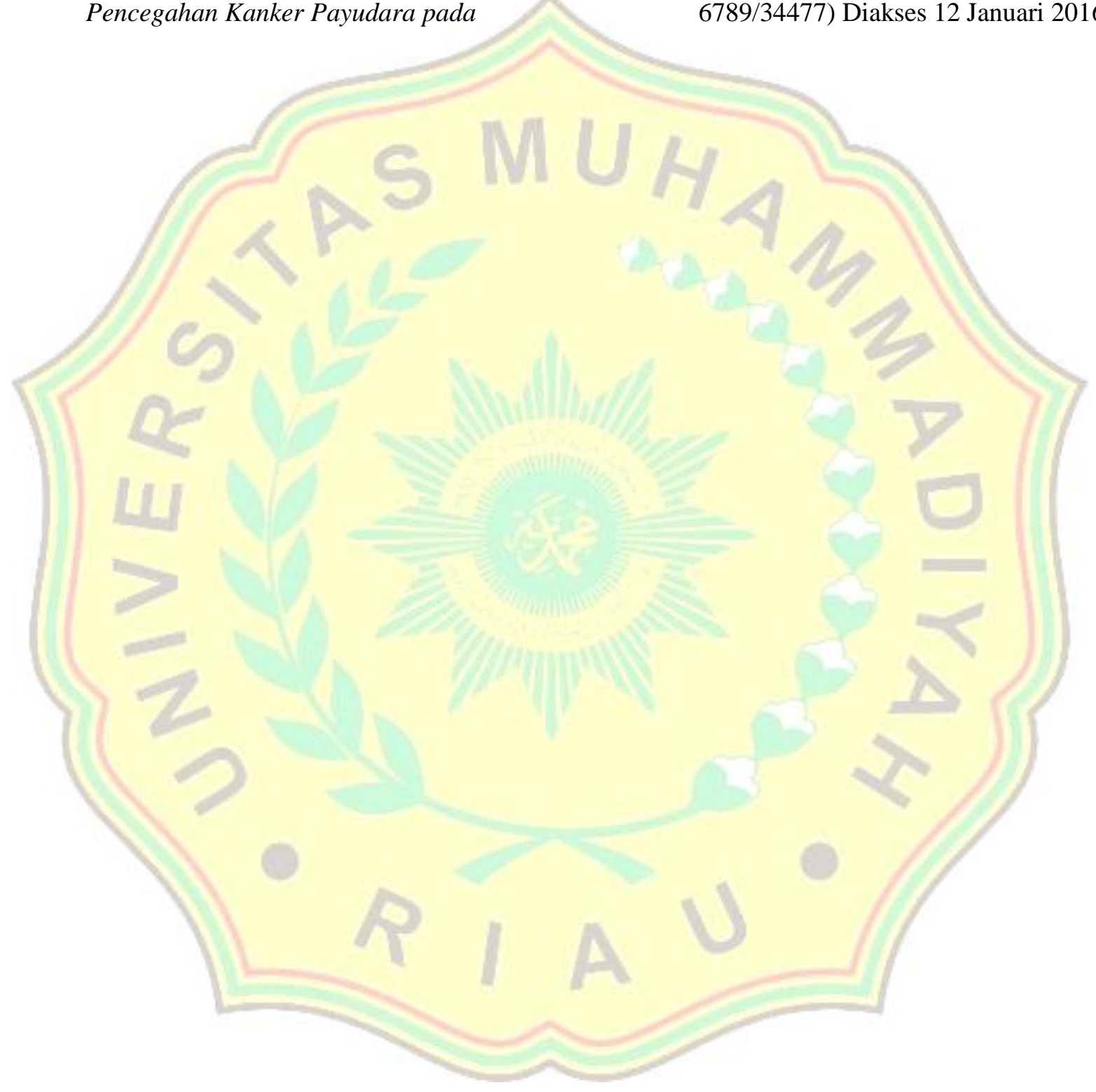

